\title{
Food biodiversity includes both locally cultivated and wild food species in Guasaganda, Central Ecuador
}

\author{
Daniela Penafiel $^{1^{*}}$ (D), Wouter Vanhove ${ }^{2}$, Ramon L. Espinel ${ }^{1}$ and Patrick Van Damme 2,3
}

\begin{abstract}
Background: Worldwide, the number of wild and domesticated food species is declining, which endangers dietary diversity of particularly indigenous people. Unfortunately, eating culture and traditional knowledge is also hampered when food species are no longer available.

Methods: This study reports the food biodiversity in Guasaganda, Central Ecuador, using a combination of methods aiming to inform local initiatives.

Results and discussion: The number of species includes 49 wild, 41 cultivated, and 28 semi-cultivated plants and 13 wild, 9 domesticated, and 1 semi-domesticated animal species. Although, Guasaganda is a hot spot of plant and animal diversity, a limited number of plant (3.00 SD 1.45) and animal species (2.37 SD 1.44) are available at the farm.

Conclusion: Increasing the number of edible species in the food system is imperative for dietary diversity. Further research should document the consumption of the reported foods, and the nutrient and biochemical content to assess nutrient adequacy of the diet.
\end{abstract}

Keywords: Food, Ecuador, Biodiversity, Nutrition, Ethnic, Indigenous

\section{Introduction}

Tropical forests are biologically diverse ecosystems that contain the highest terrestrial biodiversity per surface area. Meanwhile, 200-300 million people, mainly indigenous, are eating foods supplied by the forest; therefore, forest foods are intrinsically associated with food security [1]. Evidence shows that for forest communities the Dietary Species Richness indicator is a good proxy for micronutrient adequacy local diets [2, 3]. Unfortunately, forests and their biodiversity are quickly disappearing around the world. Deforestation and the consequent reduction in genetic resources, that includes several food species, is affecting diets at local, national, and global levels $[4,5]$ jeopardising the achievement of Sustainable Development Goal (SDG) 2 and 15. Therefore, sustainable development strategies require a detailed list of edible species that belong to the forest system.

\footnotetext{
*Correspondence: ddpenafi@espol.edu.ec

${ }^{1}$ Rural Research Center, Escuela Superior Politécnica del Litoral, Via Perimetral

Km 30.5, P.O Box 09-01-5863, Guayaquil, Ecuador

Full list of author information is available at the end of the article
}

Forests directly or indirectly supply goods and services that contribute to human nutrition in particular of indigenous communities [6]. To illustrate, in $2011,10.9 \mathrm{~kg}$ of edible non-timber forest products (NTFPs) were consumed per capita around the world, with $9.4 \mathrm{~kg}$ of NTFPs consumed per person in Latin America alone, whereas only $4 \mathrm{~kg} /$ capita was consumed in developed countries [7]. Indigenous peoples of Peru get about $90 \%$ of their dietary energy from no less than 200 species collected in the Amazon forest $[8,9]$. It is estimated that some Amazon communities which consume a high number of foods collected from the forest have a high intake of protein, fibre, 6 vitamins, and 4 minerals [8]. In the Brazilian Amazon, the consumption of fruits was found to offer an alternative protection from mercury toxicity (from gold-mining activities), as people who consumed 62 fruits in 1 week exhibited lower mercury intake than those eating mercury-exposed fish [10]. These studies show the invaluable contribution of the forest to indigenous diets and to dietary diversification.

(c) The Author(s). 2019 Open Access This article is distributed under the terms of the Creative Commons Attribution 4.0 International License (http://creativecommons.org/licenses/by/4.0/), which permits unrestricted use, distribution, and reproduction in any medium, provided you give appropriate credit to the original author(s) and the source, provide a link to the Creative Commons license, and indicate if changes were made. The Creative Commons Public Domain Dedication waiver (http://creativecommons.org/publicdomain/zero/1.0/) applies to the data made available in this article, unless otherwise stated. 
Studies on rural communities show that their diets are usually based on a wide number of wild and cultivated foods [11-13]. In the Usambara mountains of Tanzania for example, 202 foods were part of the diet, with $41 \%$ of them obtained from farms and $2.6 \%$ obtained from the forest [14]. In South-West Nigeria, 27 wild foods are gathered from natural forests as well as 13 medicinal plants [15]. In the Lombok island of Indonesia, 111 plant species are part of diets consisting of 69 meals, 71 snacks, and 11 beverages [16]. In Buzios (Brazil), 65 different wild animal species are eaten, with fish being the most important source of animal protein [17]. In the Brazilian Amazon, 40 different fruit species are consumed [10]. In two rural districts of Meru in Eastern Kenya, 23 cultivated and three wild food species are part of the agricultural biodiversity [18]. More importantly, more recent evidence merging data from several lowand middle-income countries shows that the increase on one additional species in the diet the nutrient adequacy for micronutrients raises 0.03 points [2].

Beyond dietary diversity, different food species supply indigenous people with services that can be perceived to have a direct (i.e. spiritual needs, eating habits, food culture) or indirect value (i.e. carbon sequestration, nutrient recycling, nitrogen fixation) [19]. The management of these direct services associated indirect ones represent a challenge for stakeholders because indigenous perceptions are deeply rooted into the culture, which suggests that when the forest is reduced, these values could also go extinct [20].

Thereafter, environmental change is a barrier to eat local food biodiversity whether wild or cultivated [21]. The reduction of forest-food availability leads people to consume annual crops that are cultivated in deforested land $[22,23]$. In response to the lack of food biodiversity inventories, this study aims to document the number of wild foods that are present in the forest of Sacha Wiwua (Central Ecuador) and foods cultivated in surrounding farms, aiming to quantify the food biodiversity, which can potentially contribute to the conservation of species that support dietary diversity and nutrient adequacy of diets.

\section{Methodology}

We followed the Food and Agriculture Organization of the United Nations (FAO) guidelines to document underutilised foods and agricultural biodiversity for food and nutrition. For the study design, the main author (DP) used as a source of information a review of different methodologies used to document food biodiversity [24]. The review process is reported elsewhere (ibid.). The three selected methodologies are listed in Table 1, which were used by us to study six food-source categories, as food biodiversity is present in a diversity of landscapes. Collecting herbarium samples is a reliable methodology to create baseline information about different food species. Interviewing local people is key to understand food biodiversity as it collects, qualitative and quantitative, information on the diversity of the ecosystem without disturbing it. To reduce the disturbance of the area and to the participants, the main author (DP) used the help of two local guides, one male and one female, to become familiar to the local paths and people. The interaction between the researcher and indigenous people is recommended to document indigenous knowledge in Ecuador according to "diálogo de saberes".

\section{Study area}

Ecuador is one of the 17 megadiverse countries of the world. The origin of this high diversity can be explained first by its neotropical location, the pronounced Andes highlands, the influence of the Pacific Ocean, and the

Table 1 Methodologies used to document plant and animal food biodiversity

\begin{tabular}{|c|c|c|c|}
\hline Method $^{a}$ & Food category & Place $^{c}$ & Data $^{d}$ \\
\hline \multirow[t]{2}{*}{ Herbarium collection } & (i) Wild plant foods & Sacha Wiwua forest & $\begin{array}{l}\text { Total number of species } \\
\text { Species use }\end{array}$ \\
\hline & (ii) Cultivated plant foods & $\begin{array}{l}\text { Surrounding arable patches of } \\
\text { Sacha Wiwua forest }\end{array}$ & $\begin{array}{l}\text { Total number of species } \\
\text { Species use }\end{array}$ \\
\hline \multirow[t]{2}{*}{ Interviews on plant foods } & (ii) Cultivated plant foods & Farms & Number of species per farm \\
\hline & (iii) Semi-cultivated plant foods & Home gardens & Number of species per home garden \\
\hline \multirow[t]{3}{*}{ Interviews on animal foods } & (iv) Wild animal foods & Communal area & $\begin{array}{l}\text { Total number of species } \\
\text { Species use }\end{array}$ \\
\hline & (v) Edible domesticated animals & Farm & $\begin{array}{l}\text { Total number of species } \\
\text { Species use }\end{array}$ \\
\hline & (vi) Semi-domesticated edible animals & Home gardens & $\begin{array}{l}\text { Total number of species } \\
\text { Species use }\end{array}$ \\
\hline
\end{tabular}

${ }^{a}$ Three methodologies which were used to document the data

${ }^{\mathrm{b}}$ Six different food categories, from (i) to (vi)

'Different studied places where data was collected

${ }^{\mathrm{d}}$ Type of data collected within each food category 
uniqueness of the Galapagos Islands. Secondly, diversity is present in its 12.8 million hectares of forests which represent $42 \%$ of the national surface area, including the Amazon forest.

Historically, Ecuador belonged to the Tahuantinsuyo together with 3 other territories (currently known as Colombia, Peru, and Bolivia) which was dominated by the Inca Empire. The Incas used to collect or hunt their foods from the forests whether in the Andes or Amazon, and they practised agriculture on communal or lodge land. However, their diets changed from being diversified to monotonous due to consumption of European foods contributing to the loss of traditional eating. A small number of indigenous people were able to eat the few traditional foods which were produced in the huasipungo (a piece of land that was borrowed to grow crops for the slaves) or collected from the remaining forest [25]. Only those hiding deep in the forest were able to maintain their eating culture.

This study was conducted in Central Ecuador, in the parish of Guasaganda (see Fig. 1). The latter is located between 250 and 1000 metres above sea level in the province of Cotopaxi, Canton La Mana. Because it is a tropical area with variable altitudes from the Andes, the temperate climate allows a wide variety of vegetation and animals to grow. In the area, around 4000 indigenous inhabitants live in the rural villages that surround the forest of Sacha Wiwua (see Fig. 1). Indigenous people of Guasaganda subsist on the food produced and gathered in their ecosystem.

\section{Herbarium collection of plant species}

To list both wild and cultivated plant foods, we collected plant samples present in the forest of Sacha Wiwua
(Central Guasaganda) and the surrounding agricultural area, respectively. By this method, the first category (wild plants) and the second category (cultivated plants) that serve as food for humans were documented. The collection of plant samples was conducted from June to August 2012, as approved by the Ministry of Environment, and by a group of trained botanical undergrads who were guided by 5 males and one female local informants. Interviewers used a semi-structured questionnaire to recall all plant with the local name and use. The inclusion criteria to identify local informants was (1) to be adult, (2) to be inhabitant of the area and being born and raised in a village close to the Sacha Wiwua forest, (3) to recognise him/her self as from indigenous ethnicity, and (4) to acknowledge their traditional knowledge of forest and cultivated foods.

In the forest, samples of edible plants were collected in line transects in the Sacha Wiwua forest and its surrounding, which were delimited by ropes and measuring tapes. The sampled forest area involved $1137.5 \mathrm{~m}^{2}$ of forest and $375 \mathrm{~m}^{2}$ of surrounding arable patches. Ten different line transects ( 7 in the forest, 3 in arable patches) were used with a minimum distance of $250 \mathrm{~m}$ between them. Because the Sacha Wiwua forest has an area of 100 ha (forest and agricultural land), our sampled transects covered $0.144 \%$ of the land.

Each plant found per transect was collected in duplicates and prepared in situ by drying the leaves in a wooden cabin using fossil gas, and subsequently placing the dried leaves in between corrugated carton panels to identify them with a unique label. The label listed country, family, scientific name, author, the area where the plant was collected, a brief taxonomic description, local

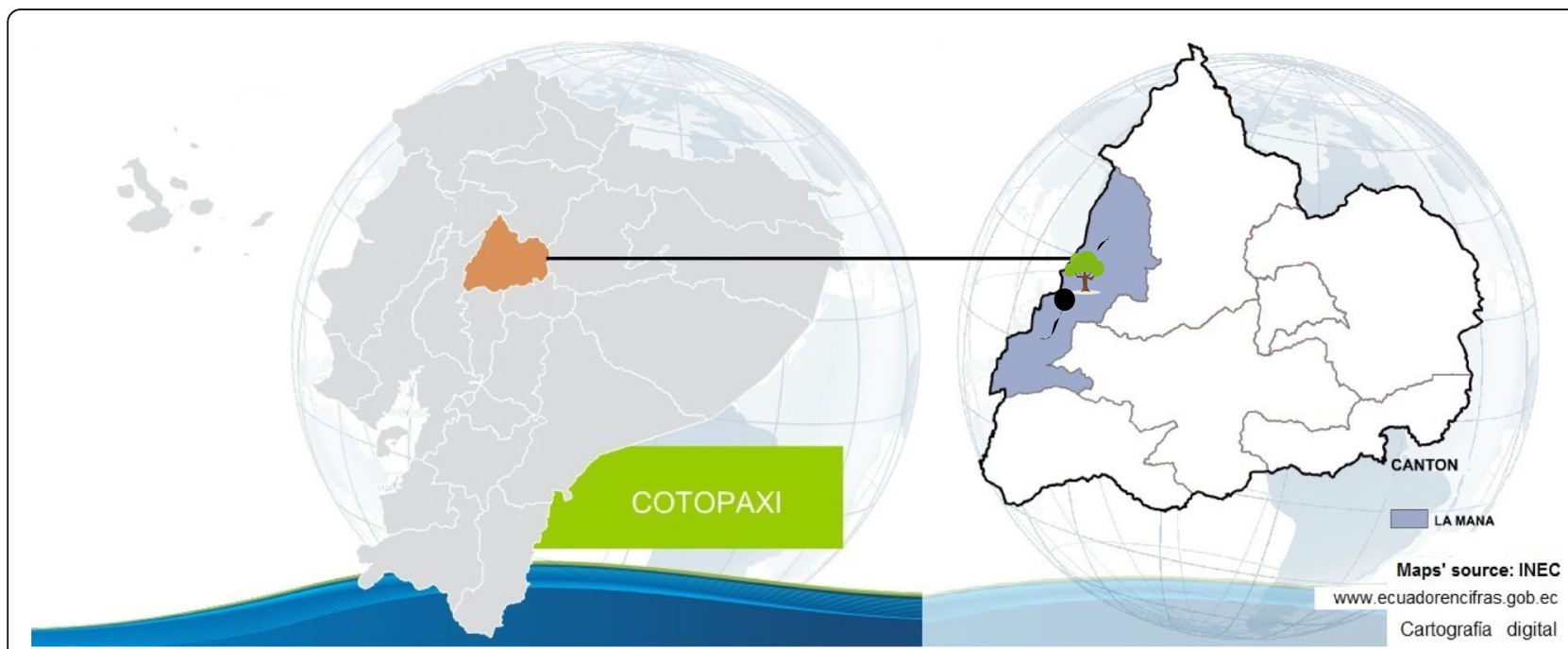

Fig. 1 Map of Ecuador, the province of Cotopaxi, and La Mana. Ecuador is located in South America and Cotopaxi is in Central Ecuador along the Andes. La Mana belongs to Cotopaxi province. The map on the right shows the location of the study area with Guasaganda (black dot) and the forest of Sacha Wiwua (tree icon). The population is mainly indigenous and their eating culture is based on traditional foods 
name, use, name of the botanist who collected the sample, an internal code, and project name.

Plant use was documented when one informant indicated the edible part and use and other two informants confirmed the information. The use was documented by transcribing their local perception (e.g. fruit, vegetable, phloem sap, starchy food, bush meat, flesh). The importance of using local classification when studying food biodiversity has been recognised elsewhere [26, 27]. The applied methodology minimised the ecosystem disturbance by collecting only the necessary plant material and using existing walking paths.

\section{Interviews on plant foods}

We conducted interviews with peasants to document the number of foods that were cultivated on the farms and were semi-domesticated in their home gardens. Interviews were conducted from July till September of 2012. A convenient sample of 137 farms was studied. All 36 villages of Guasaganda were included reaching 3 to 4 farms per village. The inclusion criteria for participants involved (1) only one person per farm, (2) who responded to be in charge of the food production, whether male or female, (3) provided oral consent to enter the farm. Plant samples were not collected at the farms.

Interviews were guided by an interviewer who asked semi-structured questions about the use, cultivation, and domestication. Per farm, the total number of edible plants was documented. Different codes were given to each cultivated and wild plant. Those species found in home gardens, which were collected from the forest, were coded as semi-cultivated (third category).

\section{Interviews on animal foods}

Group and individual interviews on animal foods were conducted in December 2012 and January 2013, respectively. Animal samples were not collected because the legislation in Ecuador does not allow collecting animals in forest areas. To document wild animal foods 3 focus groups were organised with adults (a total of 4 male and 11 female) and 3 with elderly (a total of 5 male and 6 female), each group in a different village. Adults aged from 19 to 56 years and elderly from 56 to 91 years. A total of 25 peasants were interviewed by the main author (DP) using a semi-structured questionnaire about local names and the use of wild animal foods. Interviews were recorded using a Philips digital voice tracer (LFH 0667 DNS) and a microphone. Participation to focus groups and personal interviews was voluntary with written consent before the interviews.

To document the number of domesticated animals with edible use per farm, we interviewed 40 farmers using a semi-structured questionnaire about the use and local names. Species which were reported to be in home gardens were coded as semi-domesticated.

\section{Analysis}

This study used a combination of qualitative and quantitative analysis. The herbarium collection was analysed qualitatively. Each species was coded, for the different uses (fruit, starch, plant sap, vegetables, legumes, spices, colourant, or stimulant) and category (wild, cultivated, semi-cultivated), and listed in a table using the local name, scientific name, edible use, and habitat. The count of foods according to the three categories was illustrated using bar charts.

Qualitative analysis was conducted to the transcripts of the focus groups on animal foods. To reduce bias, transcripts were coded by the author of this manuscript (DP) and an additional researcher. The list of animal foods was retrieved using NVivo (QSR, V8) for each category with the codes "animal food" "wild" and "domesticated".

The number of species present in the farm and home gardens for plant and animal species was analysed using in RStudio, Inc. Summary statistics were reported to analyse the central tendency (mean $\pm \mathrm{SD}$ ). A nonparametric two sample (Wilcoxon test) one-sided test was used to test if the mean number of semi-cultivated species was significantly higher than the number of cultivated species at the farms. Kolmogorov-Smirnov tests and box plots were used to examine normally distribution and equal variances, respectively. We used a non-parametric test because normality was not present, and the variances were not equal between groups.

The scientific name of each plant was given following the botanical binomial nomenclature and using the official names provided the local herbarium and confirmed by an online database (www.theplantlist.org, V1.1). To report the scientific names of animals online databases for Ecuadorian mammals (http://bioweb.bio/faunaweb/ mammaliaWeb/), birds (http://zoologia.puce.edu.ec/Vertebrados/aves/AvesEcuador/default.aspx), and freshwater fish (http://bibdigital.epn.edu.ec) were used.

\section{Results}

In total, 112 edible species were documented in this study. This count is the number of locally available foods of Central Ecuador, Guasaganda, which were reported as the nutrition indicator for food biodiversity for FAO [28].

\section{Plant foods}

Table 2 lists all 90 local plant species that belong to 35 botanical families which were reported to be edible during the plant inventory. According to our categorisation, 49 plant species were found in the forest and identified as wild, whereas 41 species were found to be cultivated on the farms. We identified 28 semi-domesticated 
Table 2 List of edible plant species, wild, and cultivated, in Guasaganda, Central Ecuador

\begin{tabular}{|c|c|c|c|c|}
\hline Botanical family $^{a}$ & Scientific name Author ${ }^{\mathrm{b}}$ & Local name & Edible use $^{d}$ & $\begin{array}{l}\text { Plant } \\
\text { habitat }^{\mathrm{e}}\end{array}$ \\
\hline Achariaceae & $\begin{array}{l}\text { Carpotroche longifolia } \\
\text { (Poepp.) Benth. }\end{array}$ & Huila & Fruit pulp & Small tree \\
\hline Actinidiaceae & $\begin{array}{l}\text { Saurauia tomentosa } \\
\text { (Kunth) Spreng. }\end{array}$ & Catón & Fruit pulp & Tree \\
\hline Anacardiaceae & Mangifera indica L. & Mango & Fruit pulp & Tree \\
\hline Anacardiaceae & Spondias purpurea L. & $\begin{array}{l}\text { Obito } \\
\text { Ciruela }\end{array}$ & Fruit pulp & Tree \\
\hline Annonaceae & Annona duckei Diels & Chirimoya de monte & Fruit pulp & Tree \\
\hline Annonaceae & Annona sp.* & Guanábana de monte & Fruit pulp & Tree \\
\hline Annonaceae & Annona cherimola Mill. & Chirimoya & Fruit pulp & Tree \\
\hline Annonaceae & Annona muricata $\mathrm{L}$. & Guanabana & Fruit pulp & Tree \\
\hline Annonaceae & * & Espinuda & Fruit & Palm \\
\hline Apiaceae & Eryngium foetidum L. & $\begin{array}{l}\text { Culantro de monte } \\
\text { Cilantro de monte, } \\
\text { Yumbo }\end{array}$ & Leaves & Herb \\
\hline Araceae & Colocasia esculenta (L.) Schott & Papa china & Starchy corm & Herb \\
\hline Araceae & Xanthosoma sp.* & Sango & Starchy corm & Palm \\
\hline Arecaceae & $\begin{array}{l}\text { Prestoea decurrens } \\
\text { (H. Wendl. ex Burret) H.E. Moore }\end{array}$ & Palmito & Starchy stem & Palm \\
\hline Arecaceae & $\begin{array}{l}\text { Geonoma interrupta } \\
\text { (Ruiz \& Pav.) Mart. }\end{array}$ & $\begin{array}{l}\text { Chillibo } \\
\text { Chontilla }\end{array}$ & Fruit & Palm \\
\hline Arecaceae & $\begin{array}{l}\text { Bactris gasipaes } \\
\text { Kunth }\end{array}$ & $\begin{array}{l}\text { Chontilla } \\
\text { Chontaduro }\end{array}$ & Fruit & Palm \\
\hline Bignoniaceae & $\begin{array}{l}\text { Cydista aequinoctialis } \\
\text { (L.) Miers }\end{array}$ & $\begin{array}{l}\text { Bejuco de agua } \\
\text { Pascuenque }\end{array}$ & Phloem sap & Vines \\
\hline Bixaceae & Bixa orellana $\mathrm{L}$. & Achiote & $\begin{array}{l}\text { Seed colorant } \\
\text { extract }\end{array}$ & Shrub \\
\hline Cannaceae & Canna indica $\mathrm{L}$. & Atsera & Starchy corm & Herbaceous \\
\hline Caricaceae & $\begin{array}{l}\text { Vasconcellea microcarpa } \\
\text { (Jacq.) A. DC. }\end{array}$ & Col de monte & Leaves & Shrub \\
\hline Caricaceae & Vasconcellea sp. $1^{*}$ & Papaya de monte & Fruit pulp & Tree \\
\hline Caricaceae & Vasconcellea sp.2* & Oroyuyo & Fruit pulp & Tree \\
\hline Caricaceae & Carica papaya $\mathrm{L}$. & Papaya & Fruit pulp & Tree \\
\hline Clusiaceae & Garcinia sp.* & $\begin{array}{l}\text { Mamey/mango de monte } \\
\text { Peladera }\end{array}$ & Fruit pulp & Tree \\
\hline Clusiaceae & $\begin{array}{l}\text { Tovomita weddelliana } \\
\text { Planch. \& Triana }\end{array}$ & Capuli de monte & Fruit pulp & Tree \\
\hline Convolvulaceae & Ipomoea batatas (L.) Lam. & Camote & Starchy root & Guaco \\
\hline Cucurbitaceae & Gurania sp.* & Zapallo de monte & vegetable & Guaco \\
\hline Dioscoreaceae & Dioscorea trifida L. f. & $\begin{array}{l}\text { Chambo } \\
\text { Papa chambo }\end{array}$ & Starchy tuber & Guaco \\
\hline Euphorbiaceae & Manihot esculenta Crantz & Yuca & Starchy root & Shrub \\
\hline Botanical family & Scientific name Author & Local name & Edible use & Plant habitat \\
\hline Fabaceae & $\begin{array}{l}\text { Arachis pintoi } \\
\text { Krapov. \& W.C. Greg. }\end{array}$ & $\begin{array}{l}\text { Mani forrajero } \\
\text { Pasto forraje }\end{array}$ & Seed & Herb \\
\hline Fabaceae & Inga sp.1* & Guaba de monte & Aril as fruit & Tree \\
\hline Fabaceae & Inga sp. $2^{*}$ & Guaba de monte & Aril as fruit & Tree \\
\hline Fabaceae & Inga sp.3* & Guaba de monte & Aril as fruit & Tree \\
\hline Fabaceae & Inga vera Willd. & Guaba & Aril as fruit & Tree \\
\hline
\end{tabular}


Table 2 List of edible plant species, wild, and cultivated, in Guasaganda, Central Ecuador (Continued)

\begin{tabular}{|c|c|c|c|c|}
\hline Botanical family ${ }^{a}$ & Scientific name Author ${ }^{\mathrm{b}}$ & Local name & Edible use $^{d}$ & $\begin{array}{l}\text { Plant } \\
\text { habitat }^{\mathrm{e}}\end{array}$ \\
\hline Fabaceae & Inga sp. $4^{*}$ & Guabo común & Aril as fruit & Tree \\
\hline Fabaceae & Inga insignis Kunth & $\begin{array}{l}\text { Guaba de bejuco } \\
\text { Guaba }\end{array}$ & Aril as fruit & Tree \\
\hline Fabaceae & Inga silanchensis T.D. Penn. & Guabo negro & Aril as fruit & Tree \\
\hline Fabaceae & Vicia faba L. & Haba & Legume & Herb \\
\hline Lauraceae & Persea americana Mill. & Aguacate & Vegetable & Tree \\
\hline Malvaceae & Herrania sp.* & Cacao de monte & Aril as fruit & Tree \\
\hline Malvaceae & Matisia giacomettoi Romero & Zapote de monte & Fruit pulp & Tree \\
\hline Malvaceae & Matisia sp.* & $\begin{array}{l}\text { Molinillo } \\
\text { Zapote } \\
\text { Limón }\end{array}$ & Fruit & Tree \\
\hline Melastomataceae & * & Obillo & Fruit pulp & Tree \\
\hline Moraceae & $\begin{array}{l}\text { Artocarpus altilis } \\
\text { (Parkinson) Fosberg ex. F.A Zorn Fosberg }\end{array}$ & Fruta de pan & Seed & Tree \\
\hline Moraceae & Brosimum utile (Kunth) Oken & Sandi, cacaolcillo & Fruit pulp & Tree \\
\hline Musaceae & Musa acuminata Colla & Orito & Fruit flesh & Herbaceous \\
\hline Musaceae & Musa x paradisiaca $\mathrm{L}$. & $\begin{array}{l}\text { Plátano verde, } \\
\text { barraganete }\end{array}$ & Fruit flesh & Herbaceous \\
\hline Musaceae & Musa acuminata Colla & Guineo de seda, banano & Fruit flesh & Herbaceous \\
\hline Myrtaceae & $\begin{array}{l}\text { Syzygium malaccense } \\
\text { (L.) Merr. \& L.M. Perry }\end{array}$ & Pera costena & Fruit pulp & Shrub \\
\hline Myrtaceae & $\begin{array}{l}\text { Eugenia stipitata } \\
\text { McVaugh }\end{array}$ & Arazá & Fruit pulp & Tree \\
\hline Myrtaceae & Psidium guajava $\mathrm{L}$. & Guayaba, guayabo & Fruit pulp & Tree \\
\hline Passifloraceae & Passiflora sp. $1^{*}$ & $\begin{array}{l}\text { Granadilla de monte } \\
\text { Maracuyá de monte }\end{array}$ & Fruit pulp & Guaco \\
\hline Passifloraceae & Passiflora sp.2* & $\begin{array}{l}\text { Granadilla de monte } \\
\text { Maracuyá de monte }\end{array}$ & Fruit pulp & Guaco \\
\hline Passifloraceae & Passiflora foetida $\mathrm{L}$. & $\begin{array}{l}\text { Badea de monte } \\
\text { Enredadera de monte }\end{array}$ & Fruit pulp & Guaco \\
\hline Passifloraceae & Passiflora sp. $3^{*}$ & $\begin{array}{l}\text { Granadilla de monte } \\
\text { Maracuyá de monte }\end{array}$ & Fruit pulp & Guaco \\
\hline Passifloraceae & Passiflora sp.4* & $\begin{array}{l}\text { Granadilla de monte } \\
\text { Maracuyá de monte }\end{array}$ & Fruit pulp & Guaco \\
\hline Passifloraceae & Passiflora sp.5* & $\begin{array}{l}\text { Granadilla de monte } \\
\text { Maracuyá de monte }\end{array}$ & Fruit pulp & Guaco \\
\hline Passifloraceae & Passiflora mixta L. f. & Taxo & Fruit pulp & Guaco \\
\hline Passifloraceae & Passiflora edulis Sims & Maracuyá & Fruit pulp & Guaco \\
\hline Passifloraceae & Passiflora foetida $\mathrm{L}$. & $\begin{array}{l}\text { Granadilla de monte } \\
\text { Maracuyá de monte }\end{array}$ & Fruit pulp & Guaco \\
\hline Passifloraceae & Passiflora edulis $f$. flavicarpa O. Deg. & Maracuyá & Fruit pulp & Guaco \\
\hline Poaceae & Saccharum officinarum L. & Caña de azúcar & Phloem sap & Herbaceous \\
\hline Poaceae & Zea mays $\mathrm{L}$. & Maíz & Seeds & Herbaceous \\
\hline Polygonaceae & $*$ & $\begin{array}{l}\text { Hueso de mono } \\
\text { Piñuelo } \\
\text { Motilon } \\
\text { Sacha naranjo }\end{array}$ & Fruit pulp & Tree \\
\hline Primulaceae & Clavija sp.* & $\begin{array}{l}\text { Naranjita, pepa de mono, naranjo de } \\
\text { monte }\end{array}$ & Fruit pulp & Tree \\
\hline Rosaceae & Rubus sp.** & Mora de monte & Fruit drupelets & Shrub \\
\hline
\end{tabular}


Table 2 List of edible plant species, wild, and cultivated, in Guasaganda, Central Ecuador (Continued)

\begin{tabular}{|c|c|c|c|c|}
\hline Botanical family ${ }^{\mathrm{a}}$ & Scientific name Author ${ }^{\mathrm{b}}$ & Local name ${ }^{c}$ & Edible use $^{d}$ & $\begin{array}{l}\text { Plant } \\
\text { habitat }^{\mathrm{e}}\end{array}$ \\
\hline Rubiaceae & * & Mani de monte & Pod seed & Herbaceous \\
\hline Rubiaceae & Borojoa patinoi Cuatrec. & Borojó & Fruit pulp & Tree \\
\hline Rubiaceae & $\begin{array}{l}\text { Coffea canephora } \\
\text { Pierre ex A. Froehner }\end{array}$ & Café aromático & Seed & Tree \\
\hline Rutaceae & Citrus medica L. & Lima & Fruit pulp & Tree \\
\hline Rutaceae & $\begin{array}{l}\text { Citrus } x \text { limon } \\
\text { (L.) Osbeck }\end{array}$ & Limón & Fruit pulp & Tree \\
\hline Rutaceae & Citrus reticulata Blanco & Mandarina & Fruit pulp & Tree \\
\hline Rutaceae & Citrus maxima (Burm.) Merr. & Naranja & Fruit pulp & Tree \\
\hline Rutaceae & Citrus sp. $1^{*}$ & Toronja & Fruit pulp & Tree \\
\hline Rutaceae & Citrus sp. $2^{*}$ & Toronja & Fruit pulp & Tree \\
\hline Rutaceae & Citrus sp. $3^{*}$ & Limón Mandarina & Pulp juice & Tree \\
\hline Salicaceae & $\begin{array}{l}\text { Casearia quinduensis } \\
\text { Tul. }\end{array}$ & $\begin{array}{l}\text { Vara blanca } \\
\text { Naranjito } \\
\text { Sacha naranjo } \\
\text { Manglillo } \\
\text { Naranjo de monte } \\
\text { Tarquino }\end{array}$ & Aril as fruit & Tree \\
\hline Sapotaceae & $\begin{array}{l}\text { Chrysophyllum argenteum subsp. panamense (Pittier) T.D. } \\
\text { Penn. }\end{array}$ & Caimito & Fruit pulp & Tree \\
\hline Sapotaceae & Pouteria multiflora (A.DC.) Eyma & Logma & Fruit pulp & Tree \\
\hline Sapotaceae & Chrysophyllum sp.* & Cauje & Fruit pulp & Tree \\
\hline Sapotaceae & Chrysophyllum argenteum Jacq.* & Caimito & Fruit pulp & Tree \\
\hline Solanaceae & $\begin{array}{l}\text { Solanum sesiliflorum } \\
\text { Dunal }\end{array}$ & Naranjilla de monte & Fruit pulp & Shrub \\
\hline Solanaceae & Solanum sp.* & Naranjilla de monte & Fruit pulp & Shrub \\
\hline Solanaceae & Solanum lycopersicum L. & Tomate & Fruit pulp & Herbaceous \\
\hline Solanaceae & Solanum sp.* & Naranjilla & Fruit pulp & Shrub \\
\hline Solanaceae & Solanum quitoense Lam. & Naranjilla & Fruit pulp & Shrub \\
\hline Solanaceae & $\begin{array}{l}\text { Capsicum lycianthoides } \\
\text { Bitter }\end{array}$ & $\begin{array}{l}\text { Tomate de monte, símbalo, huan } \\
\text { huan }\end{array}$ & Fruit pulp & Herbaceous \\
\hline Solanaceae & Solanum circinatum Bohs & $\begin{array}{l}\text { Tomatillo } \\
\text { Tomate de arbol }\end{array}$ & Fruit pulp & Sub shrub \\
\hline Sterculaceae & Theobroma cacao L. & Cacao & $\begin{array}{l}\text { Seed for } \\
\text { chocolate } \\
\text { Aril as fruit }\end{array}$ & Tree \\
\hline Urticaceae & Pourouma sp.* & Uva de monte & Fruit pulp & Tree \\
\hline
\end{tabular}

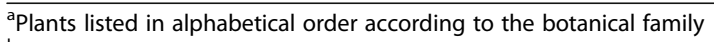

bSpecies marked with an asterisk "*" were not fully identified, and when a number is added, it refers to another species which was not fully identified but was different from the rest and therefore inventoried apart

'The local name is listed in Spanish as it was reported by the local informants

${ }^{d}$ The edible use refers to the part of the plant that is consumed and the eating practice

${ }^{\mathrm{e}}$ It refers on the type of plant growth environment

species which were found in the forest and in home gardens. The number of wild and cultivated plant species is illustrated in Fig. 2.

According to the use reported by participants, out of the 90 plant species, 71 species are eaten as fruits, whereas 7 species as starch source, of only 2 species the phloem sap (the fluid of the plant) is used, 5 species are consumed as vegetables, faba beans (Vicia faba L.) as legume, cilantro de monte (Eryngium foetidum L.) is used as spice, achiote (Bixa orellana L.) as food colourant, coffee (Coffea canephora Pierre ex A. Froehner) is used as stimulant, and cacao seed (Theobroma cacao L.) is used for chocolate, and the aril as fruit. Ninety-one food items add to the list of local food biodiversity with cacao counted twice because it has two uses (seed/almond and aril). 


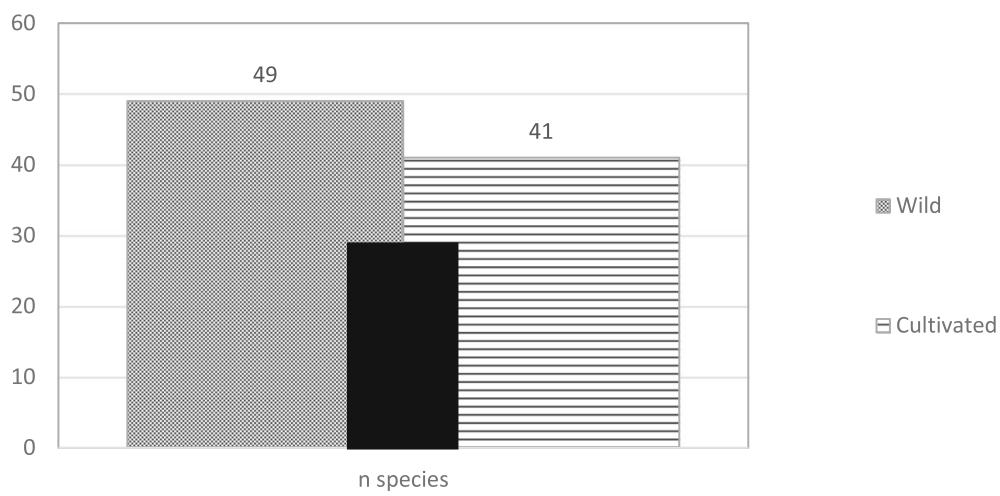

Fig. 2 Number ( $n$ ) of edible wild (grey bar) and cultivated (stripped bar) plants reported in Guasaganda, Ecuador. Bars show the total number of species for each category, sharing 28 semi-cultivated species which are represented by the black bar

The mean number of all edible food species (both cultivated and wild plants) is $3.10 \pm 1.45$. The mean number of edible semi-cultivated plant species is $2.5 \pm 1.3$, whereas the mean number of cultivated edible plants is $1.5 \pm 0.8$. The mean number of semi-cultivated plants on the farms is significantly higher than the number of cultivated plants with a 5\% significance ( $p$ value < $0.001)$. In average, farms have 1.2 cultivated fruits and 1.2 staples, also 1.8 semi-cultivated fruits, and 1 semicultivated vegetable.

\section{Animal foods}

Animal species identified as edible include 8 freshwater fish species, 10 different mammals and 4 fowl (see Table 3). Thirteen species were reported as wild from which 10 were mentioned during the interviews to be in danger of extinction, therefore, stated to be less consumed. Nine species were identified as domesticated. Only one participant mentioned having a sahino (Tayassu pecari) on his farm (semidomesticated) and to be the only person domesticating this animal, which was confirmed by visiting the farm. Out of the 22 animal species, three fish species (campeche, cholia and pampanito) were not identified with scientific names due to the inadequate description during the interviews. The total number of food items of animal origin added up to 27 because chicken (Gallus Gallus domesticus), cow (Bos Taurus), and pig (Sus domesticus) had more than one use. The mean land designated to animal husbandry is 13 ha with a minimum of 0.2 ha and a maximum of 50 ha. The mean animal species in the studied farms is $2.37 \pm$ 1.44. The number of wild and domesticated animal species is illustrated in Fig. 3.

\section{Additional findings}

An additional plant use, which was reported during interviews, is medicinal plants. The latter plants were not grouped as foods, because participants did not associate their consumption with energy intake (no kcal intake), but they were associated with a medicinal use. Table 4 lists the plants perceived as medicinal by our respondents and the medicinal use documented elsewhere. Medicinal plants are prepared as infusions, known as "aguas aromáticas", which are consumed in a frequency of 3 times per day. Medicinal infusions can be prepared using any of the 14 different plant leaves ( 7 found in the forest and 7 in home gardens).

Interviews with local farmers allowed us to document the traditional diet. Respondents mentioned that their diet is composed of mainly three meals per day, and often a local fruit is consumed between meals. Usually, milk is consumed in the morning immediately after milked. The first meal is mainly composed of local starchy food, which is accompanied by a small portion of protein such as eggs or cheese. Lunch contains plantains whether cooked, fried, or roasted in preparations with fish, beef, pork, or cheese. People collect fruits from the forest or the farm, and they eat and share the raw fruit with neighbours or family. Maize is consumed in salads or in pastry. In the evening, medicinal tea with "panela" (sugar cane produce) is consumed. The photos of the most consumed foods can be seen in Additional file 1.

\section{Discussion}

This study demonstrates that 112 edible species are available at top of the food system for consumption whether wild, semi-cultivated, or cultivated. Also, 14 medicinal plants were reported because they were perceived as having an important role in food biodiversity. Indigenous people in Guasaganda, Ecuador, can diversify their diets by consuming local wild, semi-cultivated, and cultivated foods. Wild foods include 49 plant and 13 animal species whereas cultivated foods include 41 plant and 9 animal species. A meta-analysis of 26 different countries has reported that in order to increase dietary diversity in one food group, farmers require to increase 
Table 3 List of edible animal species available in Guasaganda, Ecuador

\begin{tabular}{|c|c|c|c|}
\hline English name ${ }^{a}$ & Scientific name $e^{b}$ & Local name ${ }^{c}$ & Food use $^{d}$ \\
\hline Armadillo* & Cabassous centralis & Cachicambo / Ardamillo & Flesh \\
\hline Small mouth fish* & Ichthyoelephas humeralis & Bocachico & Flesh \\
\hline Campeche fish & Not identified & Campeche & \\
\hline Cavia & Cavia porcellus & Cuy & Flesh \\
\hline Chicken & Gallus gallus domesticus & Gallina / Pollo & $\begin{array}{l}\text { Flesh } \\
\text { Eggs }\end{array}$ \\
\hline Cholia fish * & Not identified & Cholia & Flesh \\
\hline Cow & Bos taurus & Vaca / Res & $\begin{array}{l}\text { Flesh, Liver } \\
\text { Stomach }\end{array}$ \\
\hline Deer * & Mazama nemorivaga & Venado & Flesh \\
\hline Duck & Cairina moschata domestica & Pato & Flesh \\
\hline Fox $*$ & Cerdocyon thous & Zorro & Flesh \\
\hline Goose & Anser Anser & Ganso & Flesh \\
\hline Guatuza * & Dasyprocta punctata & Guatuza & Flesh \\
\hline Huajia fish * & Physiculus talarae & Pescado Huajia & Flesh \\
\hline Paca * & Cuniculus paca & Guanta & Flesh \\
\hline Pig & Sus domesticus & $\begin{array}{l}\text { Chancho } \\
\text { cerdo domestic }\end{array}$ & $\begin{array}{l}\text { Flesh } \\
\text { Liver } \\
\text { Intestine }\end{array}$ \\
\hline Sheep & Ovis aries & Borrego domestic & Flesh \\
\hline Tachuela fish * & Corydoras hastatus & Tachuela & Flesh \\
\hline Tilapia fish & Tilapia mossambique & Tilapia & Flesh \\
\hline Turkey & Meleagris gallopavo & Pavo & Flesh \\
\hline Old lady fish & Andinocara sp. & Vieja & Flesh \\
\hline Pampanito fish & Not identified & Pampanito & Flesh \\
\hline Sahino * & Tayassu pecari & Cerdo sahino & Flesh \\
\hline
\end{tabular}

${ }^{a}$ English name used to list the food in alphabetical order.

"Species marked with an asterisk "*" were reported as in danger of extinction.

'Local name is listed in Spanish as reported by the informants.

${ }^{d}$ The food use refers to the part of the animal that is used for food.

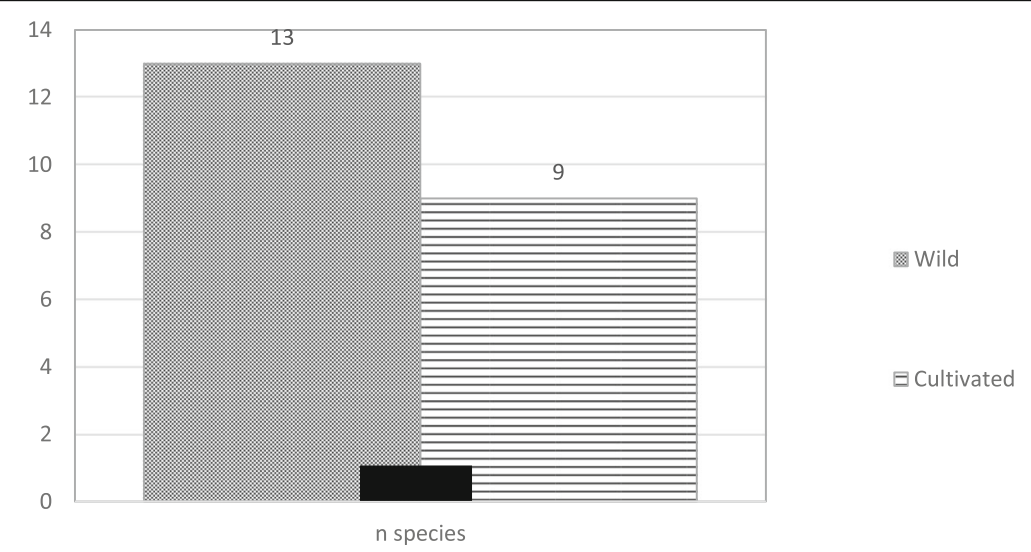

Fig. 3 Number ( $n$ ) of edible wild (grey bar) and domestic (stripped bar) animals reported as edible in Guasaganda, Ecuador. Bars show the total number of species for each category, sharing one species which was semi-domesticated and it is represented by the black bar 
Table 4 Locally wild or semi-cultivated plants with medicinal use in Guasaganda, Ecuador, that are reported elsewhere

\begin{tabular}{|c|c|c|c|c|c|}
\hline $\begin{array}{l}\text { English } \\
\text { name }^{a}\end{array}$ & Scientific name author ${ }^{b}$ & Local name & Medicinal use ${ }^{d}$ & $\begin{array}{l}\text { Number of } \\
\text { responses }^{\mathrm{e}}\end{array}$ & Reference \\
\hline Basil & Ocimum basilicum L. & Albahaca & To cure stomach pain & 4 & {$[29,30]$} \\
\hline $\begin{array}{l}\text { Lemon } \\
\text { grass }\end{array}$ & Cymbopogon citratus (DC.) Stapf & Hierba luisa & Stomach pain, flatulence, relaxing & 5 & {$[29,31]$} \\
\hline Mastrante & $\begin{array}{l}\text { Lippia alba (Mill.) N.E.Br. ex Britton \& } \\
\text { P.Wilson }\end{array}$ & Mastrante & To heal stomach pain & 3 & [29] \\
\hline Guayusa & Ille guayusa Loes. & Guayusa & $\begin{array}{l}\text { To heal headaches and stomach pain, } \\
\text { energising drink }\end{array}$ & 3 & {$[30,32]$} \\
\hline Guanabana & Annona muricata $\mathrm{L}$. & Guanabana & To heal fever during flue, cancer & 3 & [29] \\
\hline Balm & Melissa officinalis L. & Toronjil & To heal stomach pain, gastritis and to relax & 3 & {$[29,31]$} \\
\hline Mint & Mentha $\times$ piperita $\mathrm{L}$. & $\begin{array}{l}\text { Menta/Hierba } \\
\text { buena }\end{array}$ & To heal headaches during cold and to relax & 3 & {$[29]$} \\
\hline Lemon & Citrus limon (L.) Osbeck & Limon & Aroma therapy & 6 & [32-34] \\
\hline Mandarine & Citrus reticulata Blanco & Mandarina & Aroma therapy & 3 & [33] \\
\hline Orange & Citrus maxima (Burm.) Merr. & Naranja & Aroma therapy & 3 & {$[33]$} \\
\hline Grapefruit & Citrus sp. ${ }^{*}$ & Toronja & For taste and aroma & 3 & {$[33]$} \\
\hline Valerian & Valeriana officinalis $L$. & Valeriana & To relax, to sleep better & 3 & {$[29,31]$} \\
\hline Urtica & Urera sp.* & Ortiga & \multirow{2}{*}{$\begin{array}{l}\text { To cure headaches, stomach pain, } \\
\text { inflammations, relax. }\end{array}$} & 3 & {$[30]$} \\
\hline Urtica & Urtica sp.* & Ortiga verde & & 3 & {$[30,35]$} \\
\hline
\end{tabular}

${ }^{a}$ English name used to list the food in alphabetical order

"Species marked with an asterisk "*" were not fully identified

'The Spanish name as reported by the participants

${ }^{\mathrm{d}}$ The medicinal use listed refers only to the use reported by participants

${ }^{\mathrm{e}}$ Number of responses by participants about the referred medicinal plant

${ }^{\text {f }}$ References used to confirm the reported medicinal use (see the reference list)

the number of species in 16 crops or livestock [36]. The latter infers that dietary diversity can potentially be reached by farmers only when they cultivate in regions with high food biodiversity.

Our study is the first reporting the availability of local food species in the forest of Sacha Wiwua and surrounding farms. An additional study has reported that traditional knowledge to cultivate/raise the reported foods or collect/hunt them from the forest, and to prepare them in traditional meals is a solid behavioural factor present which, in all age groups, is positively influencing dietary diversity in Guasaganda [21]. Both studies are to inform any local intervention to promote the cultivation of food biodiversity in the area aiming dietary diversity and sustainability of the food system.

Our study reports a higher number of food species compared with other studies conducted in other South American indigenous communities $[8,10,13]$. The main reason is that we used a double-layer methodology to record 6 different categories of foods. Our combined methodology interviewed peasants who described the food biodiversity including all wild, cultivated, and semicultivated plants and animal foods by using scientific names, which was lacking in the literature. Sustainable nutrition interventions towards SDG2 require measuring a combination of indicators in order to assess all the food system, including the total number of species.

A previous study on dietary species richness in Guasaganda reported a list of food species consumed, including raw and industrially processed foods documented from 24-hour dietary intake recalls [2]. The list, however, does not specify the number of locally cultivated foods. The study of Passos et al. (2007) reported only a list of traditional fruits and fish in the Brazilian Amazon recorded by 7-day intake record for only fish and fruit intake. The list of fruit species is limited to 40 species recorded during the studied season, which excludes fruits with different seasonality. Two studies conducted in the same area in the Peruvian Amazon reported a different number of traditional food species. The study of Roche et al. (2008) reported the consumption of 20 TFs in the Peruvian Amazon but did not use scientific names, whereas Creed-Kanashiro et al. (2009) identified 82 traditional foods using scientific names. The combination of collecting food samples and interviews is necessary to document all foods regardless of seasonally.

Our findings suggest that the provision of fruits is an ecosystem service of the Sacha Wiwua forest. Our results indicate that indigenous people in Guasaganda have mainly fruits (71 species) available for consumption 
whereas few staples (7 species) and vegetables (5 species) are available. Because fruits are an important source of micronutrients, it seems imperative to promote the consumption of local wild and cultivated fruits for health. A body of evidence shows that wild fruits are rich in micronutrients, antioxidants, and phytochemicals which are essential for health [37]. Also, these are culturally acceptable and therefore easy to incorporate into nutrition interventions [21]. Termote et al. (2012) reported that consumers of wild edible foods in D.R. of Congo consumed significantly more fruits than non-wild food consumers. Boedecker et al. (2014) found likewise that wild-edibles consumers had a significantly higher Women Dietary Diversity Scores than non-wild edible consumers. Consistently, Powel et al. (2013) propose that despite wild foods minimally contribute to energy intakes they contribute to dietary diversification. The number of species available in the studied traditional food system has been reported to contribute to dietary diversification of rural women [3].

Despite the total high number of food species reported in this study, a limited number of cultivated fruit and vegetables species and staples per farm was observed. High food biodiversity in the studied region (defined as the total number of edible species inventoried) is thought to be a necessary but not a sufficient condition to find a large farm diversity (cultivated and semicultivated species). A reason for the low number of plant species found at the studied farms might be that farmers in Guasaganda are dedicated to family farming, which is characterised by sharing and interchanging foods between farmers in a community. Furthermore, the main income-generating activity is animal feed production and bovine milk production, which limits the number of species to a few commercial species. A few animals (Holstein, Gyr and Jersey) and pastures (such as Axonopus scoparius (Flüggé) Kuhlm., Paspalum dilatatum Poir, Brachiaria decumbens Stapf) are prevailing. Further research requires conducting an analysis of milk production's impact combined with forest conservation incentives and the restoration of pastures. There exists evidence that the combination of milk production and forest conservation, in southern Ecuador, would not eliminate poverty among small farmers because incentives are insufficient (ibid.).

The additional finding of this study is that home gardens are sites used for the domestication of wild species, which have mainly a medicinal use. The study of home gardens composition and plant species richness is increasing in tropical countries [38]; however, further research of Ecuadorian home gardens is still needed [39, 40]. Because most of our home gardens informants were female, we suggest that future interventions in Guasaganda should concentrate on the empowerment of women to manage home gardens particularly for the cultivation of medicinal plants and vegetables. Medicinal plants are important to be promoted as these are used to prevent diseases and vegetables because there are only a few vegetables present at the farms.

Additionally, bio scientist should study home gardens as a supplier of medicinal plants. Biochemical analysis of medicinal plants is required to identify the bio components responsible for the medicinal properties claimed by indigenous people and validate results in Table 4 .

\section{Conclusion}

Nature provides humans with a number of species that serve as food to have a high dietary diversity, which is the basis for healthy diets. In highly biodiverse food systems are the combination of the forest, farms, and home gardens that supply with a large number of species, which are eaten by peasants and their families. However, the number of cultivated species in the farm is limited (particularly vegetables) whereas the higher number of species (particularly fruits) are in the forest. Local cultivation of vegetables and medicinal plants is highly recommended. This study guides future strategies that promote the reduction of malnutrition and deforestation aiming human and environmental health.

\section{Supplementary information}

Supplementary information accompanies this paper at https://doi.org/10. 1186/s42779-019-0021-7.

Additional file 1. Annex 1. Number of Plant and Animal species with edible use. Annex 2. Most consumed fruits. Annex 3. Most consumed starchy foods. Annex 4. Most consumed protein source. Annex 5. The food system

\section{Abbreviations}

DOI: Digital object identifier; ESPOL: Escuela Superior Politécnica del Litoral; FAO: Food and Agriculture Organization of the United Nations; NTFPs: Nontimber forest products; SD: Standard deviation; SDG: Sustainable Development Goal

\section{Acknowledgements}

Many thanks to Holger Cevallos, Ronald Vinces, and Angelica Torres at Escuela Superior Politécnica del Litoral, for their methodological recommendations.

\section{Authors' contributions}

All authors made substantial contributions to the conception and design of the work. DP and PV were responsible for the acquisition of the data. DP and $\mathrm{W}$ conducted the analysis and interpretation of data. All authors have drafted the final version of the work with substantial revisions and have approved the submitted version.

\section{Authors' information}

The main author (DP) is a professor and researcher at Escuela Superior Politécnica del Litoral with special interest on Human Nutrition and Rural Development. She shares indigenous ethnicity and is devoted to nutrition education for the conservation of natural resources in Ecuador and sustainable diets. Her post doc in Columbia University is related to Ecuadorian dietary guidelines using local food species towards SDG2. She 
linked the following authors to conduct the present study. Dr. WV is currently working at the Department of Plant and Crops at Ghent University, Belgium. He has ample experience in conservation and use of agrobiodiversity in underutilised Latin-American foods. Prof. RE was Dean of the Faculty of Life Sciences at Escuela Superior Politécnica del Litoral with special interest on research in the field of Agricultural Economics and Natural Resources. Currently, he directs the rural Research Centre in ESPOL. Prof. PVD lectures and provides practical training for Bio-Engineers of the FBE at Ghent University, specialised in Agricultural Sciences and Land and Forest Management. PVD also is a lecturer at the Faculty of Tropical AgriSciences, Czech University of Life Sciences (Prague, Czech Republic).

\section{Funding}

This work was funded by the International Foundation for Science under grant code E- 4954-1.

\section{Availability of data and materials}

The data that support the findings of this study are openly available in figshare at https://figshare.com/articles/DataSET_Food_Biodiversity_ Guasaganda/7520258, DOI: https://doi.org/10.6084/m9.figshare.7520258. In addition, the former DOI shares the research permits for botanical collection and participant's interviews.

\section{Ethics approval and consent to participate}

The Ecuadorian Ministry of Environment provided a scientific permit allowing researchers to collect plant samples (permit no. 03-12IC-FAU-FLO-OPAC/MA). The Ministry of Health provided approval for the interview on food consumption (MSP-DIS-0056-2012). All protocols were revised and approved by the institution review board at Escuela Superior Politécnica del Litoral (ESPOL).

\section{Competing interests}

The authors declare that they have no competing interests.

\section{Author details}

${ }^{1}$ Rural Research Center, Escuela Superior Politécnica del Litoral, Via Perimetral Km 30.5, P.O Box 09-01-5863, Guayaquil, Ecuador. ${ }^{2}$ Faculty of Bioscience Engineering, Ghent University, Coupure links 653, Ghent, Belgium. ${ }^{3}$ Faculty of Tropical Agrisciences, Czech University of Life Sciences Prague, Prague, Czech Republic.

Received: 8 January 2019 Accepted: 1 October 2019 Published online: 19 December 2019

\section{References}

1. Pimentel D, McNair M, Buck L, Pimentel M, Kamil J. The value of forest to world food security. Human Ecology. 1997;25(1):91-119.

2. Lachat $C$, Raneri JE, Smith KW, Kolsteren $P$, Van Damme $P$, Verzelen $K$, et al. Dietary species richness as a measure of food biodiversity and nutritional quality of diets. Proceedings of the National Academy of Sciences. 2018; 115(1):127.

3. Penafiel D, Cevallos-Valdiviezo H, Espinel R, Van Damme P. Local traditional foods contribute to dietary diversity and species richness of rural women's diet in Ecuador: Public Health Nutrition. 2019;22(16):2962-971.

4. Johns T, Eyzaguirre PB. Linking biodiversity, diet and health in policy and practice. Proceedings of the Nutrition Society. 2006;65(2):182-9.

5. Frison, E.A., J. Cherfas, and T. Hodgkin, Agricultural biodiversity is essential for a sustainable improvement in food and nutrition security Sustainability, 2011. 3: p. 238-253.

6. Vinceti B, Termote C, Ickowitz A, Powell B, Kehlenbeck K, Hunter D. The contribution of forests and trees to sustainable diets. Sustainability. 2013; 5(11):4797.

7. FAO. State of the world's forests in brief. Enhancing the socioeconomic benefits from forests 2014 December 12, 2014].

8. Roche M, Creed-Kanashiro H, Tuesta I, Kuhnlein H. Traditional food diversity predicts dietary quality for the Awajún in the Peruvian Amazon. Public Health Nutrition. 2008;11(05):457-65.

9. Kuhnlein H, Erasmus B, Pigelsky D. Indigenous peoples' food systems: the many dimensions of culture, diversity and environment for nutrition and health. Rome: Food and Agriculture Organization of the United Nations; 2009.
10. Passos CJS, Mergler D, Fillion M, Lemire M, Mertens F, Guimarães JRD, Philibert A. Epidemiologic confirmation that fruit consumption influences mercury exposure in riparian communities in the Brazilian Amazon. Environmental Research. 2007;105(2):183-93.

11. Kuhnlein H, Receveur O. Dietary change and traditional food systems of indigenous peoples. Annual Review of Nutrition. 1996;16(1):417-42.

12. Kuhnlein HV, Receveur O, Soueida R, Egeland GM. Arctic indigenous peoples experience the nutrition transition with changing dietary patterns and obesity. Journal of Nutrition. 2004;134(6):1447-53.

13. Creed-Kanashiro H, Roche M, Tuesta I, Kuhnlein H. Indigenous peoples' food systems: the many dimensions of culture, diversity and environment for nutrition and health. Chapter 4 Traditional food system of an Awajun community in Peru. Rome: Food and Agriculture Organization of the United Nations; 2009

14. Powell C, Hall J, Johns T. Forest cover, use and dietary intake in the East Usambara mountains, Tanzania. International Forestry Review. 2011;13(3).

15. Osemeobo GJ. Wild plants in everyday use: conservation towards sustainable livelihoods in Nigeria. International Journal of Sustainable Development and World Ecology. 2001;8(4):369-79.

16. Sukenti K, Hakim L, Indriyani S, Purwanto Y, Matthews PJ. Ethnobotanical study on local cuisine of the Sasak tribe in Lombok Island, Indonesia. Journal of Ethnic Foods. 2016;3(3):189-200.

17. Begossi A, Richerson PJ. Biodiversity, family income and ecological niche - a study on the consumption of animal foods on Buzios Island (Brazil). Ecology of Food Nutrition. 1993;30(1):51-61.

18. M'Kaibi F, Steyn NP, Ochola S, Du Plessis L. Effects of agricultural biodiversity and seasonal rain on dietary adequacy and household food security in rural areas of Kenya. BMC Public Health. 2015:15(442).

19. Sthapit B, Rana R, Eyzaguirre $P$, Jarvis $D$. The value of plant genetic diversity to resource-poor farmers in Nepal and Vietnam. International Journal of Agricultural Sustainability. 2008;6(2):148-66.

20. Lewis JL, Sheppard SRJ. Ancient values, new challenges: indigenous spiritual perceptions of landscapes and forest management. In: Society \& Natural Resources: Routledge; 2005. p. 907-20.

21. Penafiel D, Termote C, Lachat C, Espinel R, Kolsteren P, Van Damme $P$. Barriers to eating traditional foods vary by age group in Ecuador with biodiversity loss as a key issue. Journal of Nutrition Education and Behavior. 2016:48(4):258-68.

22. Nasi R, Taber A, Vliet NV. Empty forests, empty stomachs? Bushmeat and livelihoods in the Congo and Amazon Basins. International Forestry Review. 2011;13(3):355-68.

23. Arnold M, Powell B, Shanley P, Sunderland T. Editorial: forests, biodiversity and food security. The international forestry review. 2011;13(3):259-64 https://www.jstor.org/stable/24310704.

24. Penafiel D, Lachat C, Espinel R, Van Damme P, Kolsteren P. A systematic review on the contributions of edible plant and animal biodiversity to human diets. EcoHealth. 2011:8:381-99.

25. Yacelga S, Larrea, Vaca M. Conocimientos, actitudes y practicas sobre costumbres y creencias alimentarias de madres de niños menores de cinco años, madres lactantes y madres embarazadas, en tres comunidades rurales de las etnias negra, meztiza e indigena de la provincia de Imbabura (Ecuador). Revista Latinoamericana de Agricultura y Nutricion. 2004;2(3):9-15.

26. Van den Eyden V. Use and management of edible non-crop plants in Southern Ecuador: PhD dissertation. Ghent University; 2004.

27. Termote C. Wild edible plant use in Tshopo District, DR of Congo: PhD thesis. Ghent University; 2012.

28. Rittenschober D, Charrondiere R. FAO/INFOODS report on the nutrition indicators for biodiversity - food composition and food consumption: Global Progress Report; 2013. Available from: http://www.fao.org/docrep/01 9/i3559e/i3559e.pdf

29. Zambrano L, Buenaño M, Mancera N, Jiménez E. Ethnobotanical study of medicinal plants used by rural inhabitants of the parish San Carlos Quevedo in Ecuador: Universidad y Salud; 2015.

30. Diedier L. Cuaderno del promotor de salud intercultural, H. M, Editor. Quito: PETROAMAZONAS EP; 2011.

31. de la Torre L, Navarrete H, Muriel P, Macia M, Balslev H. Enciclopedia de las Plantas útiles del Ecuador. Quito: Herbario QCA-PUCE \& Herbario AAU-Univ; 2008. p. 949.

32. Aguirre Á, Tapia C, Tacán M, Monteros A, Brito B. Estudio de los Recursos Fitoterapeúticos Ancestrales para su Conservación y Aprovechamiento Sostenible; 2013 
33. Moya A. Atlas alimentario de los pueblos indígenas y afrodescendientes. Costa: Sierra y Amazonía; 2011. Available: https://biblio.flacsoandes.edu.ec/ shared/biblio_view.php?bibid=123514\&tab=opac

34. Tene V, Malagon O, Finzi PV, Vidari G, Armijos C, Zaragoza TS. An ethnobotanical survey of medicinal plants used in Loja and ZamoraChinchipe, Ecuador. Journal of Ethnopharmacology. 2007;111(1):63-81.

35. Cerón C. Plantas medicinales de los Andes ecuatorianos: Botánica Económica de los Andes Centrales; 2006. p. 285-93.

36. Sibhatu K, Qaim M. Review: Meta-analysis of the association between production diversity, diets, and nutrition in smallholder farm households. Food Policy. 2018;77:1-18.

37. Bvenura C, Sivakumar D. The role of wild fruits and vegetables in delivering a balanced and healthy diet. Food Research International. 2017;99(1):15-30.

38. Sujarwo W, Caneva G. Ethnobotanical study of cultivated plants in home gardens of traditional villages in Bali (Indonesia). Human Ecology. 2015;43(5): 769-78

39. Coomes OT, Ban N. Cultivated plant species diversity in home gardens of an Amazonian peasant village in Northeastern Peru. In: Economic Botany: The New York Botanical Garden; 2004. p. 420-34.

40. Galhena DH, Freed R, Maredia KM. Home gardens: a promising approach to enhance household food security and wellbeing. Agriculture \& Food Security. 2013;2(1):8.

\section{Publisher's Note}

Springer Nature remains neutral with regard to jurisdictional claims in published maps and institutional affiliations.

Ready to submit your research? Choose BMC and benefit from:

- fast, convenient online submission

- thorough peer review by experienced researchers in your field

- rapid publication on acceptance

- support for research data, including large and complex data types

- gold Open Access which fosters wider collaboration and increased citations

- maximum visibility for your research: over $100 \mathrm{M}$ website views per year

At BMC, research is always in progress.

Learn more biomedcentral.com/submissions 